\title{
Identification of differentially expressed genes involved in the regression and development of the chicken Müllerian duct
}

\author{
YONJU HA ${ }^{1}$, AKIRA TSUKADA ${ }^{1}$, NOBORU SAITO ${ }^{1}$, DAVID ZADWORNY ${ }^{2}$ and KIYOSHI SHIMADA*,1 \\ ${ }^{1}$ Laboratory of Animal Physiology, Graduate School of Bioagricultural Sciences, Nagoya University, Nagoya, Japan and \\ ${ }^{2}$ Department of Animal Science, McGill University, Sainte-Anne-de-Bellevue, Quebec, Canada
}

\begin{abstract}
Müllerian ducts of male chickens undergo regression around day 12 of incubation, but the underlining mechanisms remain unclear. The purpose of this study was to identify factors that contribute to regression of the Müllerian duct in the chicken. We first employed annealing control primer-based RT-PCR to screen candidate genes differentially expressed in the Müllerian ducts between male and female. Four differentially expressed genes (MSX2, GAL10, VCP and $P L C H 1)$ were partially sequenced. The expression of mRNA of the latter genes and $M S X 1$ in the male and female Müllerian ducts were compared at 7.5, 8 and 9 days of incubation using semiquantitative RT-PCR. The results indicated that both MSX1 and MSX2 mRNA was highly expressed in the male Müllerian duct at day 9 of incubation, whereas, PLCH1 mRNA was lower in the male duct at day 9 of incubation compared to that of the female duct. Although VCP mRNA was expressed in both left and right female Müllerian ducts, no expression was detected in the male duct. Whole mount in situ hybridyzation analysis showed that the expression of MSX1 and MSX2 mRNA were localized specifically in the mesenchymal cells of the male Müllerian duct at day 9 of incubation. In contrast, VCP mRNA expression was observed in both mesenchymal and epithelial cells of the female Müllerian duct but not detected in the male duct. These results suggest that both up-regulation of MSX1 and MSX2 mRNA expression is involved in the regression of the Müllerian duct in male chicken embryo, whereas VCP expression is involved in development of the female duct.
\end{abstract}

KEY WORDS: chicken, embryo, Müllerian duct, annealing control primer-based RT-PCR

\section{Introduction}

Most vertebrates have a pair of indifferent gonads at the early stages of development that later differentiate into either the testes or ovaries. Subsequently, hormones from male and female gonads induce the secondary sex characteristics, respectively. In female, due to the absence of androgens the mesonephric tubules and Wolffian ducts regress while the Müllerian ducts persist because of an absence of $\mathrm{AMH}$. The Müllerian ducts give rise to the oviducts, uterus, cervix, and contribute to the upper vagina. However in the male, $\mathrm{AMH}$ induces the regression of the Müllerian duct by binding to the AMH receptor2 (Allard et al., 2000) in the mesenchymal cells of the duct (Baarends et al., 1994, di Clemente et al., 1994, Roberts etal., 1999). In a recent study, matrix metalloproteinase 2 (MMP2), a degrading enzyme of extracellular matrix, has been identified as one of possible target genes of $\mathrm{AMH}$ signal cascade in mice (Roberts et al., 2002).

In contrast to mammals, in avian species the homogametic sex is a male (ZZ) and the heterogametic sex is a female (ZW) and in most species only the left ovary and oviduct develop in females. In addition, $\mathrm{AMH}$ is produced by both the male and female embryonic gonads and $\mathrm{AMH}$ has a role in the regression of the Müllerian ducts in the male (Weniger, 1991) and the right Müllerian duct in females (Hutson et al., 1981, Teng, 1987). In the chicken, the male Müllerian ducts cease development coincident with the expression of $\mathrm{AMH}$ on day 8 of incubation and immediately undergo regression and disappear by day 12 of incubation (Romanoff, 1960, Groenendijk-Huijbers, 1962, Carre-Eusebe et al., 1996). In the female, the left Müllerian duct

Abbreviations used in this paper: MMP, matrix metalloproteinase; PLCH, phospholipase C eta; VCP, valosin containing protein .

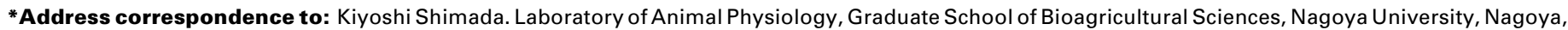
Aichi 464-8601, Japan. Fax: +81-052-789-4065. e-mail: kshimada@agr.nagoya-u.ac.jp
} 

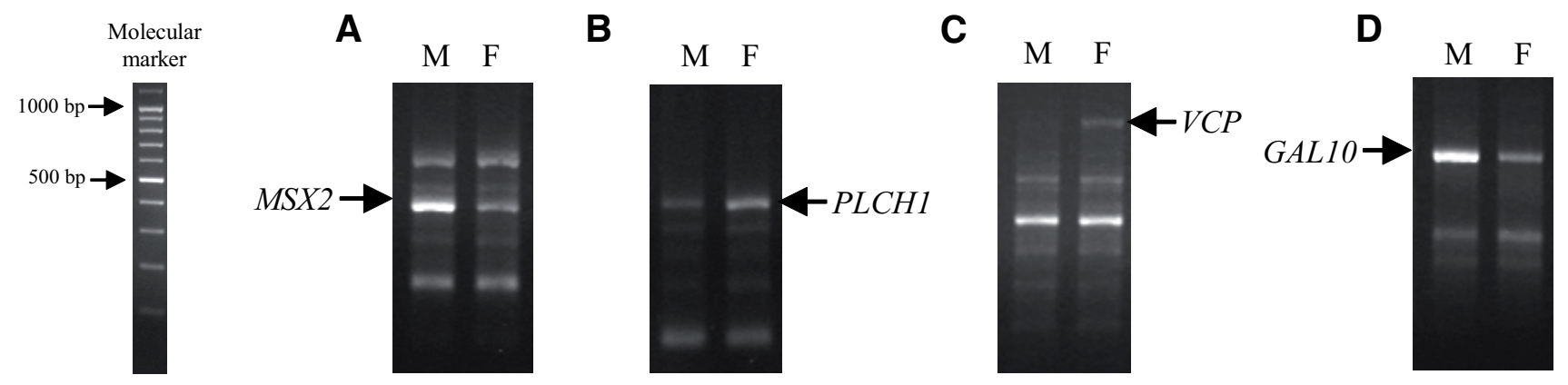

Fig. 1. Examples of gel photographs of genes differentially expressed between male left and right Müllerian ducts and female left Müllerian duct of female embryo. The male (M) and female (F) samples collected between days 7.5-9 of incubation were pooled and used for electrophoresis analysis. Arrows indicate differentially expressed genes.

continues to grow despite the expression of ovarian $\mathrm{AMH}$ and develops into the oviduct, whereas, the right duct undergoes a relatively slow involution after day 12 of incubation (Teng, 1987) and completely disappears by the time of hatching (Romanoff, 1960). Estrogen produced by the left ovary prevents $\mathrm{AMH}$ from acting on the left female Müllerian duct (Hutson et al., 1985, Teng, 2001). In part, estrogen may prevent the actions of $\mathrm{AMH}$ on then Müllerian duct by preventing an increase in expression of MMP2 in the mesenchymal cells of the Müllerian duct which may cause the degradation of the basement membrane in the duct and lead to cell death (Ha et al., 2004).

While, the regression of the Müllerian duct has been studied to some extent in mammals, the underlying molecular mechanism induced by $\mathrm{AMH}$ is still unclear in birds. Accordingly, the present study was conducted to identify factors that contribute to regression of Müllerian duct and that induce development into an oviduct in the chicken by employing the annealing control primer (ACP)-based RT-PCR analysis (Hwang et al., 2003). In this study, four differentially expressed genes, $m s h$ homeobox homologue 2 (MSX2), valosin-containing protein

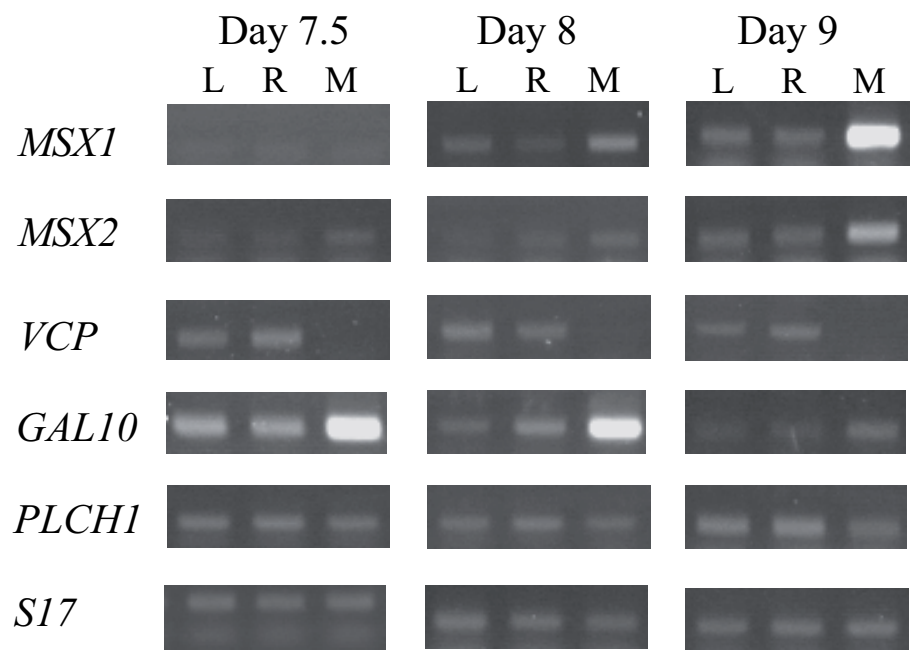

Fig. 2. Detection of mRNA transcripts of $M S X 1, M S X 2, V C P, G A L 10$ and $P L C H 1$ in the Müllerian duct at 7.5, 8 and 9 days of incubation. $L$, left female Müllerian duct; $R$, right female Müllerian duct; $M$, left and right male Müllerian ducts.
(VCP) gallinacin 10 (GAL19), phospholipase C eta (PLCH1) were obtained. The mRNA expression in the Müllerian duct of these genes was quantified by RT-PCR. Due to a high sequence identity at the nucleotide level compared to MSX2 (Coelho et al., 1992), MSX1 mRNA expression was also analyzed and the sex-specific localization of the mRNA in the duct was verified by whole mount in situ hybridization.

\section{Results}

Genes which are differentially expressed in the Müllerian ducts of the male embryo and the left duct of the female embryo

Figure 1 shows that four bands were obtained using ACP. based RT-PCR analysis. Two of them showed higher expression in Müllerian ducts of male than the female, whereas, others showed higher expression in the left duct of female than in the male. Sequence analysis indicated that those 4 genes were MSX2, VCP, GAL10 and PLCH1.

\section{Analysis of differentially expressed genes by semi-quanti- tative RT-PCR}

Figure 2 shows examples of PCR products for MSX1, MSX2, VCP, GAL 10, PLCH1 and S17mRNA of the Müllerian duct at $7.5,8$ and 9 days of incubation. Sizes were close to 332 bp, 277 bp, 418 bp, 385 bp, 134 bp and 351 bp, respectively as predicted by the above sequencing. Figure 3 shows changes in relative mRNA levels in the Müllerian duct at 7.5, 8 and 9 days of incubation following normalization to levels of $S 17$. The expression of MSX1 mRNA was low in both male and female Müllerian ducts at 7.5 and 8 days of incubation (Fig. 3A). However, MSX1 mRNA levels in the male Müllerian ducts increased markedly at day 9 of incubation and the levels were significantly higher than those of the left and the right ducts of female embryo at 9 days of incubation $(p<0.05)$. MSX2mRNA levels in male Müllerian duct were also low at 7.5 and 8 days of incubation (Fig. 3B) but significantly higher than those of the left and the right ducts of female embryo at 9 days of incubation $(p<0.05)$. VCP mRNA levels were not significantly different in the left and the right Müllerian ducts of female embryo during the examined days of incubation, but it was not detectable in the ducts of male embryo (Fig. 3C). GAL 10 mRNA levels were relatively high at day 7.5 of incubation in female and male Müllerian ducts (Fig. 3D), however the levels of the left Müllerian 
duct markedly dropped at day 8 of incubation and were minimal at day 9 of incubation. The levels in male ducts also decreased significantly at day 8 of incubation and remained low at day 9 of incubation. PLCH1 mRNA levels in the female Müllerian ducts and male duct were almost the same at days 7.5 and 8 of incubation (Fig. 3E), but at day 9 of incubation, PLCH1 mRNA levels in the left and the right Müllerian ducts of female and the male Müllerian duct increased, respectively. The levels of each duct were significantly different between days 8 and 9 of incubation, respectively $(p<0.05)$. In addition, the levels of $P L C H 1$ mRNA in the male duct were lower than those of the female ducts $(p<0.05)$.

Whole mount in situ hybridization analysis of expression of MSX1, MSX2 and VCP in the chicken urogenital system

Figure 4 shows an example of whole mount in situhybridization analysis of $M S X 1$ expression in the urogenital region at day 9 of incubation. MSX1 mRNA was only expressed in the Müllerian duct of male embryo but was not detected in the Müllerian duct of female embryo (Fig. 4A). Furthermore, the expression was not observed in either the testis or mesonephros (Fig. 4B). In the Müllerian duct of male embryo, MSX1 was detected in the mesenchymal cells and the expression was highly condensed around the epithelial cells (Fig. 4C), but was not detected in the epithelial cells. Figure 5 shows an example of whole mount in situ hybridization analysis of MSX2 expression in the urogenital region at day 9 of incubation. MSX2 mRNA was expressed only in the Müllerian duct of male embryo but was not detected in the Müllerian duct of female embryo (Fig. 5A). The expression was not detected in either the testis or mesonephros (Fig. 5B). In the Müllerian duct of male embryo, MSX2 expression was observed broadly within the mesenchymal cells but not detected in the epithelial cells (Fig. 5C). Figure 6 shows an example of whole mount in situ hybridization analysis of $V C P$ expression in the urogenital region at day 9 of incubation. VCPmRNA was expressed in the Müllerian duct of female embryo but was not detected in the Müllerian duct of male embryo (Fig. 6A). The expression was observed in mesonephros of both male and female embryos. $V C P$ expression in the gonad was observed in the left ovary but was not observed
A

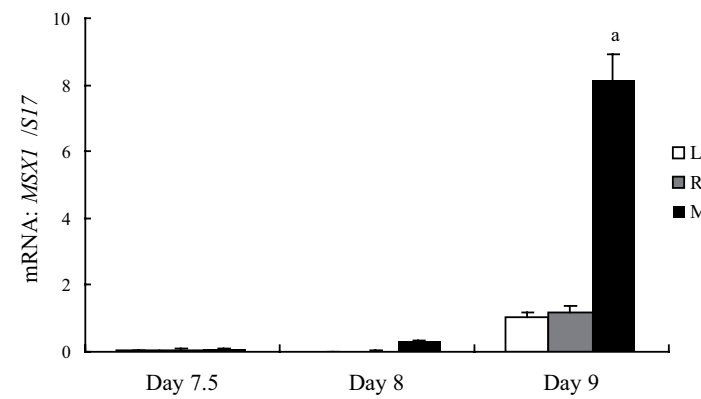

C

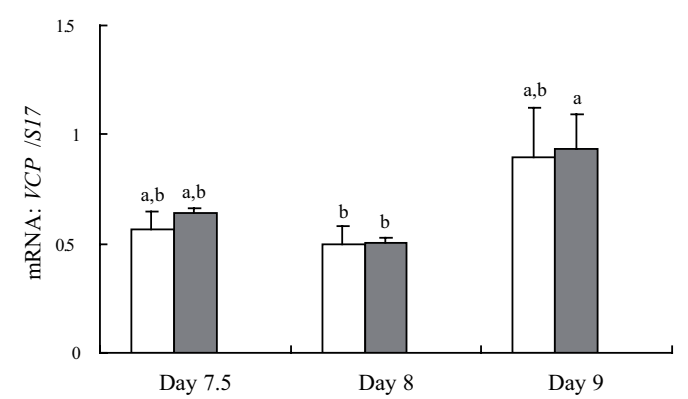

E

PLCH1

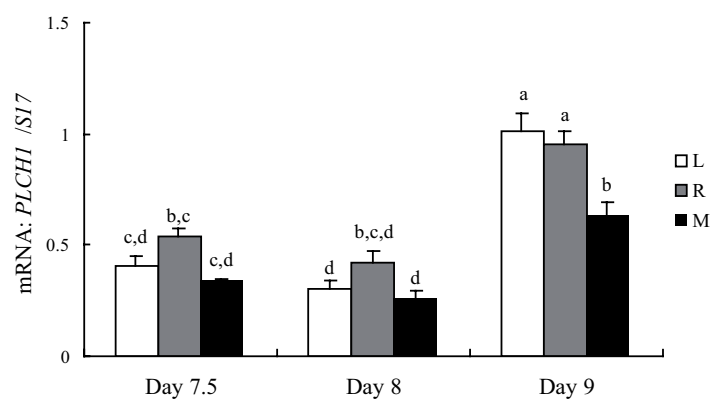

B

BSX2

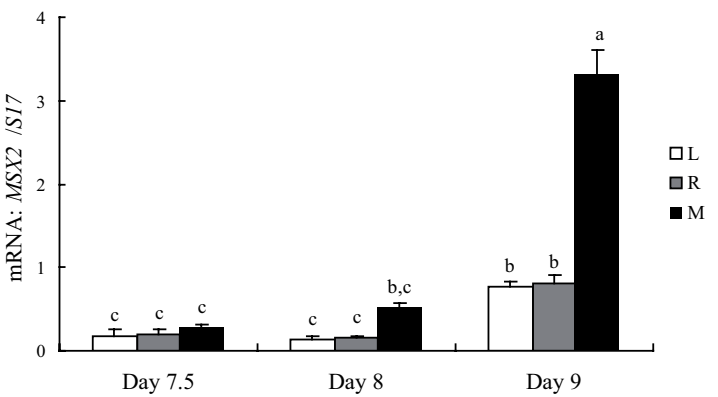

D GAL10

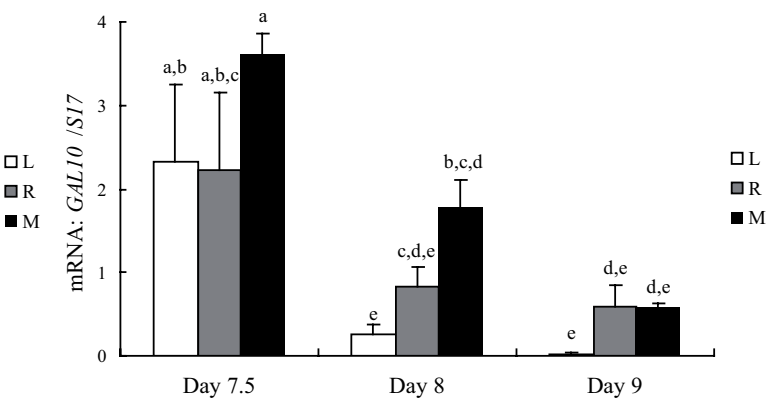

Fig. 3. Changes in mRNA expression encoding (A) MSX1, (B) MSX2, (C) VCP, (D) GAL10 and (E) $P L C H 1$ in the Müllerian duct at 7.5, 8 and 9 days of incubation. The results were displayed as means \pm SEM $(n=8)$. Means with different letters are significantly different $(p<0.05)$. Other abbreviations as in Fig. 2. 


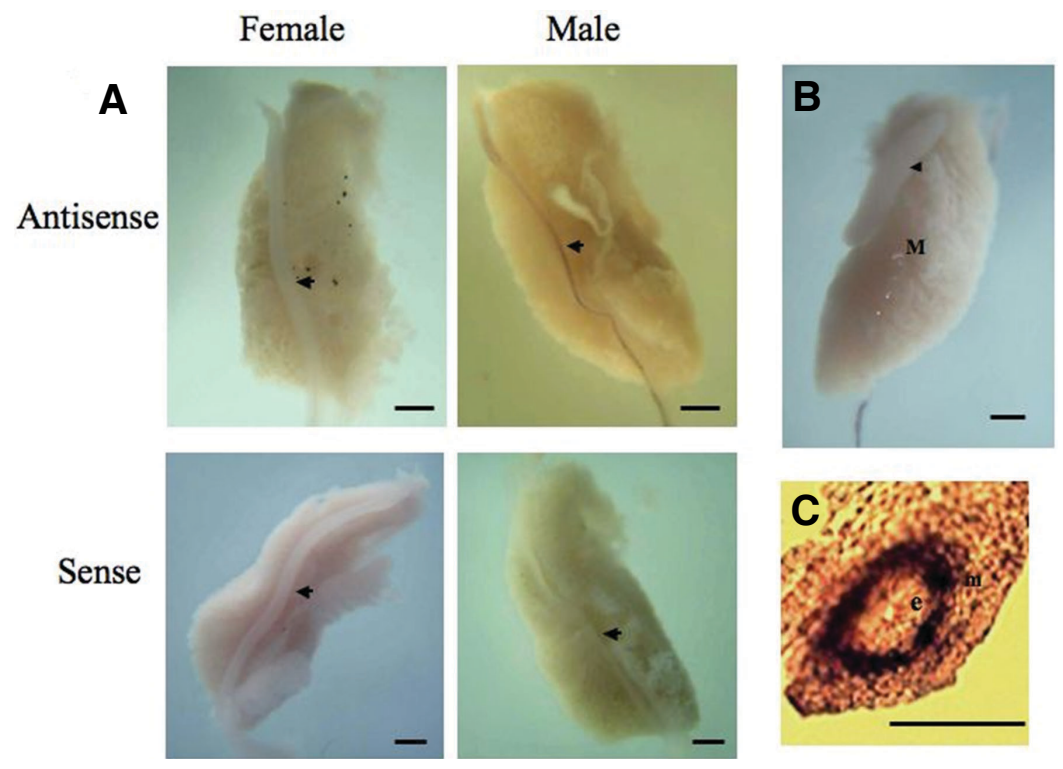

Fig. 4. Expression of $M S X \boldsymbol{1}$ in the urogenital region at day 9 of chicken embryo. Whole mount in situ hybridization analysis of MSX1 expression in female and male. (A) MSX1 expression was only detected in the male Müllerian duct, but is not detected in the female Müllerian duct. (B) MSX1 was not detected in testis (arrowhead) and mesonephros (M). (C) Cross section of male Müllerian duct shows localization of MSX1 expression in mesenchymal cells $(\mathrm{m})$; this gene is highly expressed around epithelial cells (e). Scale bars, $(A, B) 500 \mu \mathrm{m},(C) 0.5 \mu \mathrm{m}$

in the testis (Fig. 6B, C). Although the expression was observed in both epithelial and mesenchymal cells, the expression in epithelial cells was higher than that of mesenchymal cells (Fig. $6 \mathrm{D})$.

\section{Discussion}

This is the first report showing that the expression of $M S X 1$ and MSX2genes is involved in the regression of the Müllerian duct of male chicken embryo. Previous studies reported that MSX1 and MSX2 are a member of muscle homeobox genes, expressed in a various developing tissue such as limb (Coelho et al., 1991, Coelho etal., 1992), neural tube and crest (Davidson, 1995, Tribulo et al., 2004, Ying et al., 2004), branchial arches (Graham et al., 1996) and regressing Wolffian duct (Yin et al., 2006) where cell death occurs. Our results using RT-PCR assay showed high expression of $M S X 1$ and $M S X 2$ in the regressing male duct but not in the developing female duct at day 9 of incubation, indicating a significant role for the simultaneous expression of MSX1and MSX2.

Fig. 5. Whole mount in situ hybridization analysis of MSX2 expression in the male and female urogenital region at day $\mathbf{9}$ of incubation. (A) MSX2 expression was only detected in the male Müllerian duct, but was not detected in the female Müllerian duct. (B) MSX2 was not detected in testis (arrowhead) and mesonephros (M). (C) Cross section of male Müllerian duct shows localization of MSX2 expression in mesenchymal cells $(m)$, but not in epithelial cells (e). Scale bars, (A,B) $500 \mu \mathrm{m}$; (C) $0.5 \mu \mathrm{m}$.
Furthermore, whole mount in situ hybridization results in this study clearly demonstrated localization of $M S X 1$ and $M S X 2$ mRNA in the regressing duct. Namely, both MSX1 and MSX2 mRNA were expressed in the mesenchymal cells but not in the epithelial cells, more specifically, MSX1 mRNA expression in the mesenchymal cells was condensed around the epithelial cell region, whereas MSX2 mRNA was expressed broadly in the mesenchymal cells. It should be noted that the mesenchymal cells are the sites of MMP2 expression, which results in degradation of the basement membrane leading to the regression of the Müllerian duct (Roberts et al., 2002, Ha et al., 2004). We propose that MSX1 and MSX2are new mesenchymal factors in the Müllerian duct involved in the duct regression in the male chicken embryo.

$V C P$ gene was also shown to have sexually dimorphic expression in the Müllerian duct. $V C P$ belongs to $A A A$ (A TPases associated with various cellular activities) family, and is essential for a wide variety of cellular functions such as ubiquitin/ proteasom-dependent protein degradation, membrane fusion, cell cycle regulation, and endoplasmic reticulum-associated degradation (Latterich et al., 1995, Zhang et al., 2000, Dai and Li, 2001, Ye et al., 2003, Wang et al., 2004, Vandermoere et al., 2006). Expression of $V C P$ mRNA was female specific as indicated by the RT-PCR results and clearly demonstrated by whole mount in situ hybridization in the present study. In particular, $V C P$ mRNA was strongly expressed in the posterior part of the duct, and expressed broadly in the epithelial cells and mesenchymal cells in females. It has been reported that RNA interference (RNAi) of $V C P$ reduced proliferation and promoted apoptosis of HeLa cells, indicating a crucial role of VCPfor cell survival (Wojcik et al., 2004, Vandermoere et al., 2006). These results and the present data suggest that $V C P$

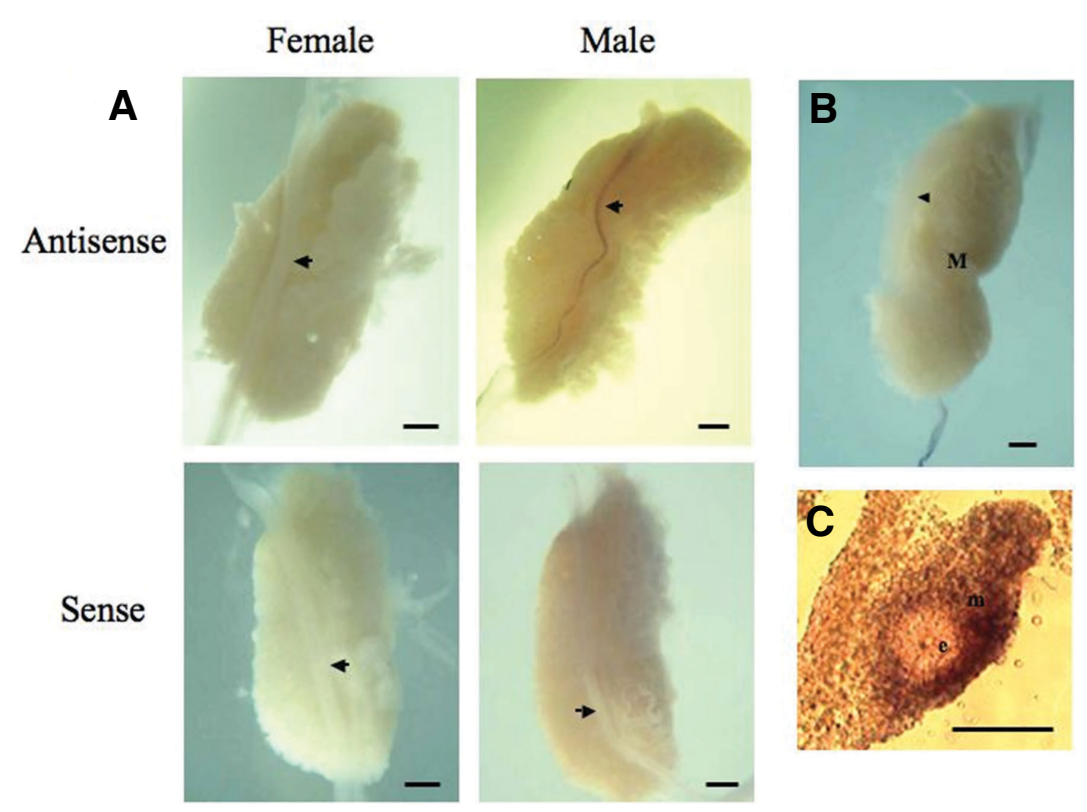




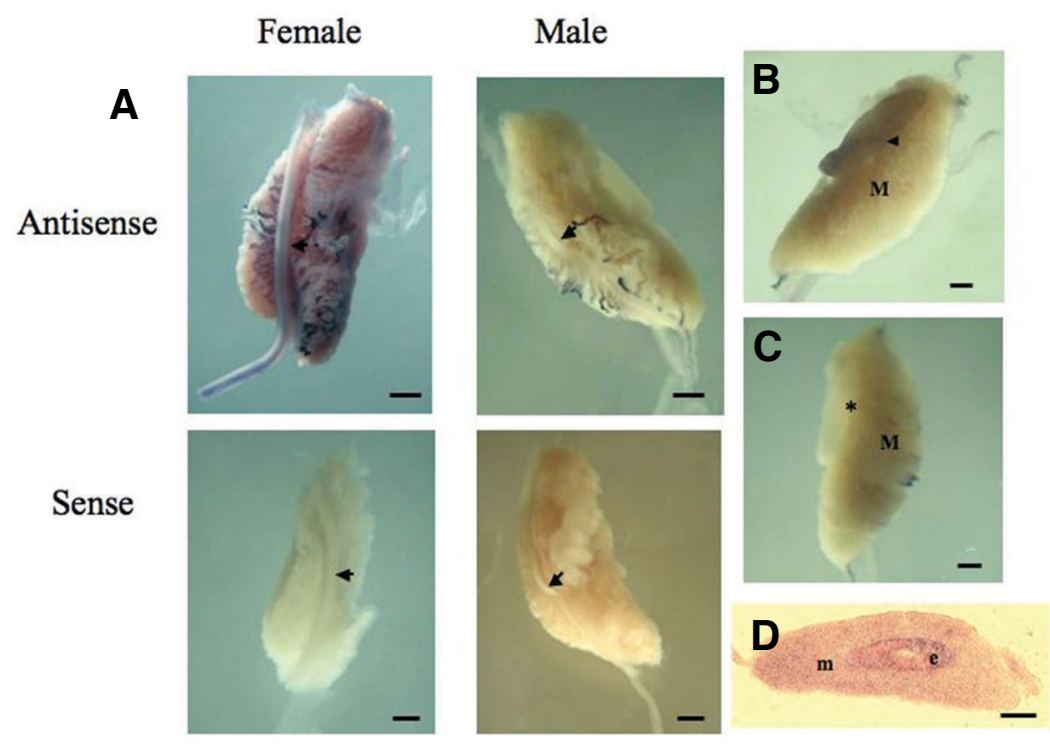

Fig. 6. Whole mount in situ hybridization analysis of valosin-containing protein (VCP) expression in the male and female urogenital region at day 9 of incubation. (A) VCP expression was only detected in the female Müllerian duct; it was not detected in the male Müllerian duct. (B) VCP expression was also detected in the left ovary (arrowhead) and mesonephros (M), but not in the testis (*) (C). (D) Cross section of the left female Müllerian duct shows that VCP expression in epithelial cells (e) was higher than that in mesenchymal cells (m). Scale bars, (A, B,C) $500 \mu \mathrm{m}$; (D) 0.5 $\mu \mathrm{m}$.

may be involved in cell proliferation and is anti-apoptotic in the Müllerian duct in the female chicken.

$P L C H 1$ is a recently discovered class of isoforms of phospholipase $C(P L C)$ that is involved in the inocitol signaling pathway (Nakahara et al., 2005, Stewart et al., 2007). In females, the expression of PLCH1 mRNA increased in the Müllerian duct at day 9 of incubation to significantly higher levels than that observed in the males. This suggests that PLCH1 may play a role in the ducts at about the stage when ducts are committed to either further development or regression. In mammals, PLCH1 is expressed mainly in neuronal tissue and similar to the other 5 classes of PLC isozymes is involved in protein kinase $C$ activation and calcium metabolism. Since its discovery in 2005, most studies have focused on its role in neurons (Stewart et al., 2007) and this is first report to show that $P L C H 1$ is expressed in the Müllerian duct during the development. What the functional role may be requires further investigation.

Although left-right asymmetric development of Müllerian ducts is a unique feature of birds, we failed in showing any difference in MSX1, MSX2, VCP, PLCH1 and GAL10 mRNA levels between left and right ducts in female chick embryos at least during the period of 7.5 - 9 days of incubation. In this regard, we (Ha et al., 2004) suggested that $\mathrm{AMH}$ after binding to $\mathrm{AMH}$ receptor in the right duct induces the expression of MMP2 expression in the mesenchymal cells, which in turn causes the degradation of basement membrane or regressing duct at days $12-18$ of incubation in the chicken embryos. Thus, the right duct regression in female starts at day 12 of incubation, we might have missed a crucial day of incubation in this study. Therefore, a possibility that some of the genes are involved in the regression after day 9 of incubation cannot be excluded. The involvement of MSX1, MSX2and VCP at the later stage of development in the asymmetric formation of Müllerian ducts warrants future study.

In summary, we propose a possible molecular mechanism underlying the regression of Müllerian ducts in the chicken as follows: In males, upregulation of $M S X 1$ and $M S X 2$ expression in mesenchymal cells of the duct and low expression of $V C P$ around day 9 of incubation may stimulate MMP2expression, which provokes degradation of the basement membrane of the Müllerian ducts, resulting to the duct regression. In contrast, in females, high expression of $V C P$ mRNA and low expression of MSX1 and MSX2 may suppress $M M P 2$ expression, hence, inhibiting cell death but promoting estrogen-induced cell proliferation or oviductal growth.

\section{Materials and Methods}

\section{Embryos}

A total of 120 fertilized chicken eggs (White Leghorn) were obtained from a commercial supplier and incubated at $37.5^{\circ} \mathrm{C}$ under humid conditions. Müllerian ducts were collected as a pooled sample on days 7.5, 8, 9 of incubation for ACP-based RT-PCR analysis. For RT-PCR assay, Müllerian ducts were collected individually at days $7.5,8$ and 9 of incubation. The collected tissues were immediately immersed in RNAlater (Qiagen, Hilden, Germany) and kept at $4^{\circ} \mathrm{C}$ until use. All procedures for the use and the care of animals were conducted after approval by the Institutional Animal Care and Use Committee of Nagoya University.

\section{ACP-based RT-PCR analysis}

Total RNA was isolated from both left and right Müllerian ducts of male embryo and only left Müllerian duct of female embryo on days 7.5, 8 , 9 of incubation using Macherey-Nagel Nucleospin RNA II kit (Macherey-Nagel, Germany). Reverse transcription was performed for $90 \mathrm{~min}$ at $42^{\circ} \mathrm{C}$ in a final volume of $20 \mu \mathrm{l}$ containing $3 \mu \mathrm{g}$ of total RNA, $4 \mu \mathrm{l}$ of $5 X$ RT buffer, $5 \mu$ l of dNTP (each $2 \mathrm{mM}$ ), $2 \mu \mathrm{l}$ of $10 \mu \mathrm{M}$ cDNA synthesis primer dT-ACP1 (Gene-Fishing TMDEG kits, Seegene, Korea), $0.5 \mu$ l of RNase inhibitor (40 U/ $\mu \mathrm{l}$, Invitrogen, Carsbad, CA, USA) and $1 \mu \mathrm{l}$ of Superscript II a reverse transcriptase $(200 \mathrm{U} / \mu \mathrm{I}$, Invitrogen, Carsbad, CA, USA). The reaction was stopped by incubation for 2 mins at $94^{\circ} \mathrm{C}$. First-strand cDNAs were diluted by the addition of $80 \mu l$ of diethyl pyrocarbonate (DEPC) treated water.

The PCR reactions were carried out in a final volume of $20 \mu \mathrm{l}$ containing the $3 \mu \mathrm{l}$ of $\mathrm{cDNA}, 10 \mu \mathrm{M}$ of dT ACP-2 primer, $5 \mathrm{mM}$ of arbitrary ACP primer and 2XSeeAMPTM Master Mix (GeneFishing ${ }^{\mathrm{TM}} \mathrm{DEG}$ kits, Seegene, Korea). After incubation at $94^{\circ} \mathrm{C}$ for 3 $\min , 50^{\circ} \mathrm{C}$ for $3 \mathrm{~min}$ and $72^{\circ} \mathrm{C}$ for $1 \mathrm{~min}, 40$ cycles were performed. Each cycle consisted of denaturation at $94^{\circ} \mathrm{C}$ for $40 \mathrm{sec}$, annealing at $65^{\circ} \mathrm{C}$ for $40 \mathrm{sec}$, and extension at $72^{\circ} \mathrm{C}$ for $40 \mathrm{sec}$. A final extension step of $5 \mathrm{~min}$ at $72^{\circ} \mathrm{C}$ was performed to complete the PCR. The $3 \mu \mathrm{l}$ of PCR products were run on a $2 \%$ agarose gel in 1 XTAE buffer, and stained with ethidium bromide.

\section{Sequence of differentially expressed genes}

The gel band of the differentially expressed gene was extracted and cloned into a pGEM ${ }^{\circledR}$ T Easy vector (Promega, Madison, WI, USA) and used to transform competent JM109 E.colicells (Takara bio Inc., Shiga, Japan). The colonies were grown for $16 \mathrm{hr}$ at $37^{\circ} \mathrm{C}$ on LB agar plates 
containing ampicillin, X-gal and IPTG for colony selection. The plasmids were extracted and sequenced using an automated DNA sequencer (Applied Biosystems, Foster City, CA, USA). Sequences were analyzed by searching for similarities using the BLAST of NCBI GenBank.

\section{Semi-quantitative RT-PCR}

Total RNA was isolated from Müllerian ducts of male embryo and left Müllerian duct of female embryo at 7.5, 8 and 9 days of incubation using Trizol $^{\mathrm{TM}}$ Reagent (Invitrogen, Carsbad, CA, USA). $0.4 \mu \mathrm{g}$ of total RNA was reverse transcribed in $20 \mu \mathrm{l}$ reverse transcription buffer $(50 \mathrm{mM}$ Tris- $\mathrm{HCl}$, $75 \mathrm{mM} \mathrm{KCl}, 3 \mathrm{mM} \mathrm{MgCl}$, $\mathrm{pH}$ 8.3) containing $10 \mathrm{mM}$ dithiothreitol (DTT), $0.5 \mathrm{mM}$ dNTPs, $0.5 \mu \mathrm{g}$ oligo (dT) $12-18$ and 100 units Superscript II a reverse transcriptase (200U/ $\mu$, Invitrogen, Carsbad, CA). Reverse transcription was carried out at $42^{\circ} \mathrm{C}$ for $50 \mathrm{~min}$, and incubated at $70^{\circ} \mathrm{C}$ for 15 min to inactivate the reverse transcriptase. First-strand cDNA was diluted by the addition of $30 \mu \mathrm{l}$ of diethyl pyrocarbonate (DEPC) treated water. Two microlitres of reverse transcribed CDNA was used for each PCR amplification. PCR reactions were carried out in $25 \mu \mathrm{l}$ PCR buffer $(20 \mathrm{mM}$ Tris- $\mathrm{HCl}, 100 \mathrm{mM} \mathrm{KCl}, 2 \mathrm{mM} \mathrm{MgCl}$, pH 8.0) containing $0.2 \mathrm{mM}$ dNTPs, $0.5 \mu \mathrm{M}$ each gene specific primers (Table 1 ) and 0.25 unit of Taq DNA polymerase (Takara bio Inc., Shiga, Japan). All PCR reactions were denaturated for 2 min at $94^{\circ} \mathrm{C}$. PCR condition for chicken MSX2, GAL 10 and $V C P$ consisted of $30 \mathrm{sec}$ of denaturation at $94^{\circ} \mathrm{C}, 30 \mathrm{sec}$ of annealing of $54^{\circ} \mathrm{C}$, and $30 \mathrm{sec}$ of extension at $72^{\circ} \mathrm{C}$ for 24 cycles. PCR condition for chicken MSX1 consisted of $30 \mathrm{sec}$ of denaturation at $94^{\circ} \mathrm{C}, 30 \mathrm{sec}$ of annealing of $50^{\circ} \mathrm{C}$, and $30 \mathrm{sec}$ of extension at $72^{\circ} \mathrm{C}$ for 32 cycles. PCR condition for chicken $P L C H 1$ and $S 17$ ribosomal protein consisted of 30 $\mathrm{sec}$ of denaturation at $94^{\circ} \mathrm{C}, 30 \mathrm{sec}$ of annealing of $60^{\circ} \mathrm{C}$, and $30 \mathrm{sec}$ of extension at $72^{\circ} \mathrm{C}$ each for 25 and 24 cycles. PCR reactions were completed with an additional extension at $72^{\circ} \mathrm{C}$ for $5 \mathrm{~min}$. S17 was used for standardization. The optimal number of cycles for each gene was determined by comparing band intensity after 17, 22, 27, 32 and 37 cycles of PCR. The 24 cycles for MSX2, GAL10, PLCH1, VCP and S17, and 32 cycles for MSX1 were selected for the optimal cycles, respectively. All PCR reactions were carried out on a Perkin-Elmer 9700 thermocycler (Applied Biosystems, Foster City, CA, USA). PCR products were run on a $0.8 \%$ agarose gel in $1 \mathrm{XTAE}$ buffer, and bands were visualized by ethidium bromide staining. The bands of the electrophoretic gels were analyzed using $\mathrm{NIH}$ image program (developed at the U.S. National Institutes of Health and available on the Internet at http://rsb.info.nih.gov/ nih-image/) and the level of MSX1, MSX2, GAL 10, VCPand PLCH1 were estimated after normalization to the levels of ribosomal protein $S 17$ mRNA in each sample.

\section{Whole mount in situ hybridization}

Urogenital systems were isolated from embryos on day 9 of incubation. Tissues were fixed overnight at $4^{\circ} \mathrm{C}$ in $4 \%$ paraformaldehyde in phosphate buffered saline (PBS), then dehydrated using a graded metha-

\section{TABLE 1}

\section{PRIMER SEQUENCES USED IN RT-PCR}

\begin{tabular}{cccc} 
Gene & Location & Sequence $\left(\mathbf{5}^{\prime} \rightarrow \mathbf{3}^{\prime}\right)$ & Accession number \\
\hline \multirow{2}{*}{ MSX1 } & $790-806$ & GCTGCATTCGGCATCTC & NM_205488 \\
& $1105-1121$ & AGAAATGTCCTACTGGG & Coelho CND et al. 1992 \\
MSX2 & $829-846$ & CCGTTGGACTCTATGCTA & NM_204559 \\
& $1087-1105$ & ACACTCTGAGGATCAGACT & \\
$V C P$ & $2031-2047$ & GACATCATTGACCCAGCT & NM001044664 \\
& $2431-2448$ & GGCTCTGCTGTAGAGTCT & \\
PLCH1 & $6500-6519$ & GCTAAAGTGTTGATAGTCGT & Xm422832 \\
& $6667-6683$ & ACTTACAGCAAAGGCAA & \\
GAL10 & $218-235$ & CCCACCTTCACCATCTCT & NM00100160 \\
& $583-602$ & CTTCATATGCTCCAAGAGCT & \\
S17 & $56-75$ & GCAACGACTTCCACACCAAC & X07257
\end{tabular}

nol series on ice. Sense and antisense riboprobes, specific to each gene, were transcribed in vitro from linearized plasmid containing the MSX1, $M S X 2$ and $V C P$ CDNA fragment (TABLE 1) using digoxigenin-labeled UTP (Roche, Germany) and SP6 or T7 RNA polymerase (Roche, Germany). Tissues were hybridized in a solution containing $500 \mathrm{ng} / \mathrm{ml}$ of riboprobe overnight at $55^{\circ} \mathrm{C}$. After hybridization, staining was conducted by incubation in nitroblue tetrazolium/5-bromo-4-chloro-3-indolyl phosphate (NBT/BCIP). Staining was only observed in tissues hybridized with antisense probe. For sectioning, tissues were embedded in paraffin and $8 \mu \mathrm{m}$ sections cut on a microtome. Sections were observed after counterstaining with $0.02 \%$ eosin.

\section{Statistical analysis}

Data were presented as means \pm SEM. The data were analyzed by a two-way analysis of variance (ANOVA) and a Tukey-Kramer honest significant difference (HSD) test $(\alpha=0.05)$ using JMP version 5.1.2 (SAS Institute, Cary, NC, USA).

\section{Acknowledgements}

We thank Dr. J. Petitte (Department of Poultry Science, North Carolina State University) for his kind correction of English in this manuscript. This research was supported by grant-in-aid from the Ministry of Education, Culture, Sports, Science and Technology of Japan, Special Topic Research "Sex differentiation" to K.S. (No. 17052009).

\section{References}

ALLARD, S., ADIN, P., GOUEDARD, L., DI CLEMENTE, N., JOSSO, N., ORGEBINCRIST, M.C., PICARD, J.Y. and XAVIER, F. (2000). Molecular mechanisms of hormone-mediated Müllerian duct regression: involvement of $\beta$-catenin. Deve/opment 127: 3349-3360.

BAARENDS, W.M., VAN HELMOND, M.J., POST, M., VAN DER SCHOOT, P.J., HOOGERBRUGGE, J., DE WINTER, J.P., UILENBROEK, J.T., KARELS, B. WILMING, L.G., MEIJERS, J.H., THEMMEN, A.P.N. and GROOTEGOED, J.A (1994). A novel member of the transmembrane serine/ threonine kinase receptor family is specially expressed in the gonads and in mesenchymal cells adjacent to the Müllerian duct. Development 120: 189-197.

CARRE-EUSEBE, D., DI CLEMENTE, N., REY, R., PIEAU, C., VIGIER, B., JOSSO, N. and PICARD, J.Y. (1996) Cloning and expression of the chick anti- Müllerian hormone gene. J. Biol. Chem. 271: 4798-4804.

COELHO, C.N.D., SUMOY, L., RODGERS, B.J., DAVIDSON, D.R., HILL, R.E., UPHOLT, W.B. and KOSHER R.A. (1991). Expression of the chicken homeoboxcontaining gene GHox-8 during embryonic chick limb development. Mech. Dev 34: $143-154$

COELHO, C.N.D., SUMOY, L., KOSHER R.A. and UPHOLT, W.B. (1992). Ghox7: a chicken homeobox-containing gene expressed in a fashion consistent with a role in patterning events during embryonic chick limb development. Differentiation 49: 85-92.

DAI, R.M. and LI, C.C. (2001). Valosine-containing protein is a multi-ubiquitin chaintargeting factor required in ubiquitin-proteasome degradation. Nat. Cell Biol. 3 740-744.

DAVIDSON, D. (1995). The functional and evolution of MSX genes: pointers and paradoxes. Trends Genet. 11: 405-411.

DI CLEMENTE, N., WILSON, C.A., FAURE, E., BOUSSIN, L., CARMILLO, P., TIZARD, R., PICARD, J.Y., VIGIER, B., JOSSO, N. and CATE, R.L. (1994). Cloning, expression and alternative splicing of the receptor for anti-Müllerian hormone. Mol. Endocrinol. 8: 1006-1020.

GRAHAM, A., KOENTGES, G. and LUMSDEN, A. (1996). Neural crest apoptosis and the establishment of craniofacial pattern: an honorable death. Mol. Cell Neurosci. 8: 76-83.

GROENENDIJK-HUIJBERS, M.M. (1962). The cranio-caudal regression of the right Mullerian duct in the chick embryo as studied by castration experiments and estrogen treatment. Anat. Rec. 142: 9-20.

HA, Y., TSUKADA, A., SAITO, N. and SHIMADA, K. (2004). Changes in mRNA expression of MMP-2 in the Müllerian duct of chicken embryo. Gen. Com. Endocrinol. 139: 131-136. 
HUTSON, J.M., IKAWA, H. and DONAHOE, P.K. (1981). The ontogeny of Müllerian inhibiting substance in the gonad of the chicken. J. Pediatr. Surg. 16: 822-827.

HUTSON, J.M., DONAHOE, P.K. and MACLAUGHLIN, D.T. (1985). Steroid modulation of Müllerian duct regression in the chick embryo. Gen. Comp. Endocrinol. 57: 88-102.

HWANG, I.T., KIM, Y.J., KIM, S.H., KWAK, C.I., GU, Y.Y. and CHUN, J.Y. (2003) Annealing control primer system for improving specificity of PCR amplification. BioTechniques 35: 2-6.

LATTERICH, M., FROHLICH, K.U. and SCHEKMAN, R. (1995). Membrane fusion and the cell cycle: Cdc48p participates in the fusion of ER membranes. Ce//82: 885-893.

NAKAHARA, M., SHIMOZAWA, M., NAKAMURA, Y., IRINO, Y., MORITA, M., KUDO, Y. and FUKAMI, K. (2005). A novel phospholipase C, PLC(eta)2, is a neuron-specific isozyme. J. Biol. Chem. 280: 29128-29134.

ROBERTS, L.M., SHEN, J. and INGRAHAM, H.A. (1999). Paracrine-mediated apoptosis in reproductive tract development. Dev. Biol. 208: 110-122.

ROBERTS, L.M., VISSER, J.M. and INGRAHAM, H.A. (2002). Involvement of a matrix metalloproteinase in MIS-induced cell death during urogenital development. Development 129: 1487-1496.

ROMANOFF, A.L. (1960). The avian embryo. MacMillan, New York.

STEWART, A.J., MORGAN, K., FARQUHARSON, C. and ROBERT. P.M. (2007). Phospholipase $\mathrm{C}$-eta enzymes as putative protein kinase $\mathrm{C}$ and $\mathrm{Ca}^{2+}$ signaling components in neuronal and neuroendocrine tissues. Neuroendocrinology. DOI: $10.1159 / 000107795$

TENG, C.S. (1987). Quantification of Müllerian inhibiting substance in developing chick gonads by a competitive enzyme-linked immunosorbent assay. Dev. Biol. 123: 255-263.

TENG, C.S. (2001) Differential activation of MAPK during Müllerian duct growth and apoptosis: JNK and p38 stimulation by DES blocks tissue death. Cel/ Tissue
Res. 306: 27-34.

TRIBULO, C., AYBAR, M.J., SANCHEZ, S.S. and MAYOR, R. (2004). A balance between the anti-apoptotic activity of slug and the apoptotic activity of msx1 is required for the proper development of the neural crest. Dev. Biol. 275: 325-342.

VANDERMOERE, F., YAZIDI-BELKOURA, I.E., SLOMIANNY, C., DEMONT, Y., BIDAUX, G., ADRIAENSSENS, E., LEMOINE, J. and HONDERMARCK, $\mathrm{H}$. (2006). The valosin-containing protein $(\mathrm{VCP})$ is a target of Akt signaling required for cell survival. J.Biol.Chem. 281: 14307-14313.

WANG, Q., SONG, C. and LI, C.C. (2004). Molecular perspectives on p97-VCP: progress in understanding its structure and diverse biological functions. $J$. Struct. Biol. 146: 44-57

WENIGER, J.-P. (1991). Embryonic sex hormones in birds. Int. J. Dev.Biol. 35: 17

WOJCIK, C., YANO, M. and DEMARTINO, G.M. (2004). RNA interference of valosin-containing protein (VCP/p97) reveals multiple cellular roles linked to ubiquitin/proteasome-dependent proteolysis. J. Cell Sci. 117: 281-292.

YE, Y., MEYER, H.H. and RAPOPORT, T.A. (2003). Function of the p97-Ufd1-Npl4 complex in retrotranslocation from the ER to the cytosol: dual recognition of unnubiquitinated polypeptide segments and poly ubiquitin chains. J. Cell Biol. 162: 71-84.

YIN, Y., LIN, C. and MA, L. (2006). Msx2 promotes vaginal epithelial differentiation and wolffian duct regression and dampens the vaginal pesponse to diethylstilbestrol. Mol Endocrinol. 20: 1535-1546.

YING, L., HELMS, A.W. and JOHNSON, J.E. (2004). Distinct activities of MSX1 and MSX3 in dorsal neural tube development. Development 131: 1017-1028.

ZHANG, X., SHAW, A., BATES, P.A., NEWMAN, R.H., GOWEN, B., ORLOVA, E., GORMAN, M.A., KONDO, H., DOKURNO, P., LALLY, J., LEONARD, G., MEYER, H., VAN HEEL, M., and FREEMONT, P.S. (2000). Structure of AAA ATPase p97. Mol. Cell. 6: 1473-1484.

\section{Further Related Reading, published previously in the Int. J. Dev. Biol.}

See our recent Special Issue Fertilization, in honor of David L. Garbers and edited by Paul M. Wassarman and Victor D. Vacquier at: http://www.ijdb.ehu.es/web/contents.php?vol=52\&issue=5-6

See our recent Special Issue Ear Development edited by Fernando Giraldez and Bernd Fritzsch at: http://www.ijdb.ehu.es/web/contents.php?vol=51\&issue=6-7

Abnormal sex-duct development in female moles: the role of anti-Müllerian hormone and testosterone. Zurita F, Barrionuevo F.J., Berta P, Esperanza O, Burgos M and Jimenez R. Int.J.Dev.Biol. (2003) 47:451-458

Embryonic sex hormones in birds. Weniger J.P.

Int.J.Dev.Biol. (1991) 35:1-7.
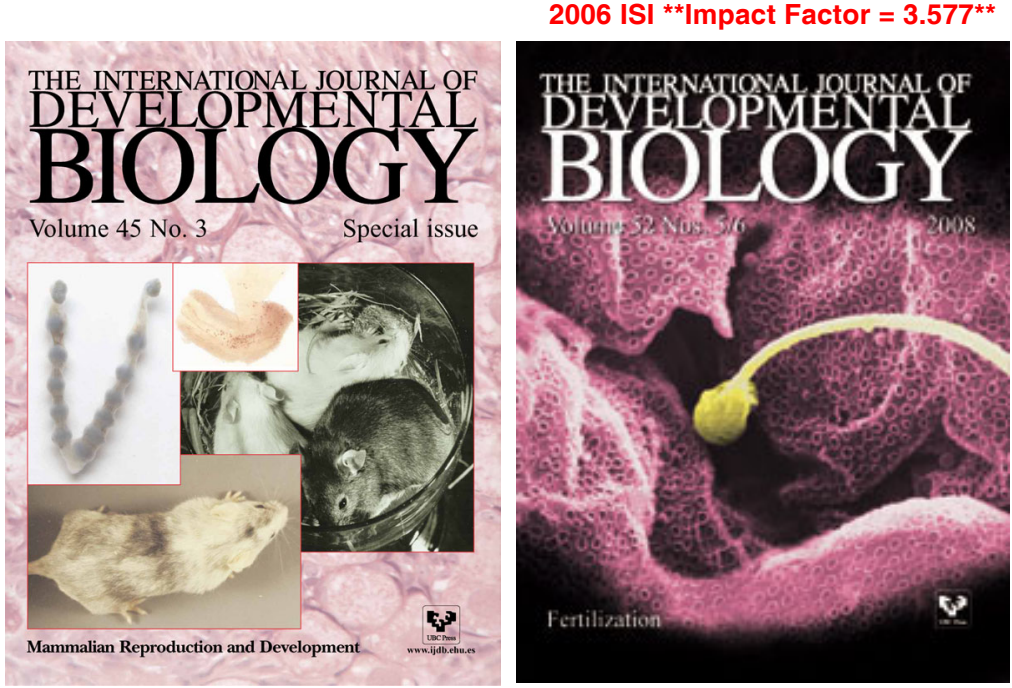